MP-585

抗 D2-40 抗体をもちいた、膀胱におけ るリンパ管分布の検討

\section{北里研究所メディカルセンター病院1), 北里大学医学部} 泌尿器科学 ${ }^{2)}$, 東邦大学医学部第二病理学 ${ }^{3)}$

溝口 秀之 ${ }^{1)}$, 宋 成浩 ${ }^{2}$, 佐藤 絵里奈 ${ }^{2)}$, 田岡 佳憲 ${ }^{2}$, 坪井 俊樹 ${ }^{1}$, 石井 壽晴 ${ }^{3\rangle}$, 馬場 志郎 ${ }^{23}$, 青 輝昭 ${ }^{2}$ 【目的】我々は、ヒト膀胱の三角部とその他の部位でリンパ 管の分布について検討した。

【対象と方法】剖検により採取された正常膀胱と、膀胱癌の 膀胱摘出標本を対象とし, リンパ管内皮に存在する $\mathrm{O}$ 型シ アロタンパクに対する抗体である抗 D2-40抗体を用いて 免疫染色を行い microlymphatics の確認をした。

【結果】D2-40 抗体陽性脈管は、粘膜にはみられず、粘膜下 層と筋層に多く分布し、筋層では筋束の間に存在した。また その密度は、正常膀胱の粘膜下層では 0.93 本 $/ \mathrm{mm}^{2}$ 、筋層で は 1.10 本 $/ \mathrm{mm}^{2}$ 、浆膜では 0.47 本 $/ \mathrm{mm}^{2}$ 、であった。

【考察】昨年報告した lymphatic endothelial hyaluronan receptor 1 で検討した結果と比較し、特に粘膜下層において 陽性脈管の著しい増加がみられた。これは、LYVE-1 抗体の 染色では検体の前処置として、加熱処理が必要であり、その ため粘膜の変性が起こったためと考えられる。また、従来の H.E 染色では、癌のリンパ管浸襲の有無についてその形態 から推測するしかなかった。しかし、今回我々の検討では明 確な microlymphaticsの染色性がみられており、膀胱癌の リンパ管浸襲の診断に D2-40 染色が有用であると考える。

\section{MP-586 膀胱癌における Hsp27 アンチセンス の抗腫瘍効果}

高知大学医学部腫瘍病態学腎泌尿器制御学教室 ${ }^{11}$, 前立 腺センター2)

鎌田 雅行 ${ }^{11}$, 村蒔 基次 ${ }^{2)}$, 執印 太郎 ${ }^{12}$, ME Gleave ${ }^{2)}$ Hsp27 は、多くの癌細胞で過剩発現しており、様々なス トレスに対し、細胞の生存に寄与している。今回我々は、 Hsp27 アンチセンスを用い、膀脱癌細胞株 (UMUC3)に おける、その抗腫瘍効果を解析した。まず、Hsp27 過剩 発現細胞株を作成し、その細胞增殖能、薬剤感受性に変 化が起こるかどうか調べた。Hsp27 過剩発現細胞株では、 有意に細胞増殖能の上昇、paclitaxelに対する感受性の低 下が見られた。そこで、Hsp27アンチセンスを作成し、 Hsp27 の発現抑制を試みた。Hsp27アンチセンスは、濃 度依存的に Hsp27 の発現を、mRNA レベル、蛋白レベル で抑制していた。 western blottingによる解析では、 cleaved caspase 3 及び PARP が出現し、このアンチセン スの処理により細胞には apoptosisが誘導されているこ とがわかった。MTT assay による細胞增殖能の解析で は、アンチセンスの処理は、濃度依存的に、有意に細胞 增殖を抑制した。さらに、 paclitaxel と Hsp27 アンチセン スの併用療法によって paclitaxel の効果が増強されるこ とがわかった。以上のことから、Hsp27アンチセンスは、 膀胱癌に対して非常に有効な治療法となり元ると考えら れた

\section{MP-587}

ヒト膀胱癌細胞に対するミドカインプ ロモーターを組み込んだ増殖制限型ア デノウイルスベクター(AD-MK-E1a) の有用性の検討

\begin{abstract}
神戸大学大学院医学系研究科腎泌尿器科学分野, , 神戸 大学医学部医学医療国際交流センター2), 愛媛大学医学 部産婦人科 ${ }^{33}$, 千葉県がんセンター研究所病理研究部 寺尾 秀治 ${ }^{1}$, 白川 利朗 ${ }^{2}$, 合田 上政 ${ }^{12}$, 濱田 雄行 ${ }^{3}$, 田川 雅敏 ${ }^{4}$, 後藤 章暢 ${ }^{2}$, 藤澤 正人 ${ }^{11}$

旧的これまでにさまざまな腫傍特異的プロモーターを組み込んだ增殖 制限型アデノウイルスベクターによる抗腄瘍効果の検討が報告されてい る。また、ミ゙カイン $(\mathrm{MK})$ は膀脱癌を舍むさまざまな癌に扔いて高い プロモーター活性を示すことが知られており、とりわけ0.6KB の MK プロモーターに抒ける腫場特異性ならびに高いプロモーター活性が報告 されている。今回我々はヒ卜膀肤癌細咆株に対する $0.6 \mathrm{~KB}$ の MKプロ モーターを組み込んだ增殖制限型アデノウイルスベクター(ADMKEla) の有用性を検討した。【方法】まずヒト膀肬癌細胞株（KK47,T24,5637) に打けるMKの発現をRT-PCR 法で確認し、Luciferase assay による MK プロモーター活性と ADMKEla の replication assay 及び細胞毒性 効果を検䛉した。また in vivo ではヌードマウスにKK47 皮下腫場を形成

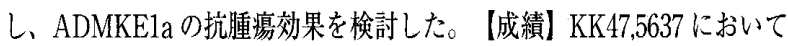
MKの高発現と高い MK プロモーター活性及び ADMKElaによる絊胞

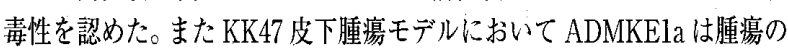
增殖を有意に抑制した。【結諭】MKを発現している膀脱癌治療に ADMKElaを用いた遺伝子治療は有用であると考元られる。
\end{abstract}

\section{MP-588}

\section{膀胱癌組織におけるリンパ管新生の臨 床的意義 と vascular endothelial growth factor (VEGF) family との関連}

\section{長崎大学大学院医歯薬学総合研究科堅泌尿器科学", 長 崎大学大学院感染病態制御学2), 長崎大学付属病院病理 部3)}

宮田 康好 ${ }^{1)}$, 神田 滋2), 大庭 康司郎 ${ }^{13}$, 野俣 浩一郎 ${ }^{12}$, 林田 靖1), 江口 二郎 ${ }^{12}$, 林 徳真吉 ${ }^{3}$, 金武 洋 ${ }^{1}$ 目的】近年、各種の癌でリンバ管新生が軽移や予後と関伱することが報告 されているが膀胀癌での臨床的意義については知られていない。また vascular endothelial growth factor (VEGF) family がリンバ管新生に影響する

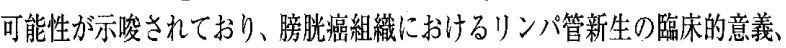
およびVEGF family との関連を检討する。(方法)経尿道的䧛肤䏸場切除術 を受けた126名（平均年秢67.8歳）を対象とした。リンパ管は抗 D2-40 抗体で免疫染色し、lymph vessel density (LVD) として半定量化した ( $/ \mathrm{mm}$

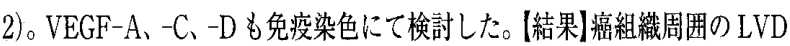

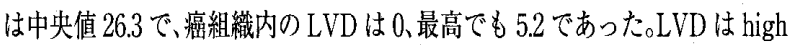
grade で有意に高値 $(\mathrm{P}=0.002)$ であったが、 $\mathrm{pT}$ stage とは関連しなかった。 Low LVD 群で 5 年生存率が $96.5 \%$ であったのに対し、high LVD 群では $80.2 \%$ であった $(\log$ rank $\mathrm{P}=0.039)$ 。次に，LVD と VEGF family の関逨を みると、VEGF-C と VEGF-Dが有意に関連していた。一方、VEGF-A と LVD の間に有意な関連仙認めなかった。【結語】膀哓癌組織では癌組織周 团にリンパ管新生が起こっていることや、リンパ管新生が予後と関連する ことが示陖された。また、VEGF family のうち、VEGF-Cおよび VEGF-D がリンパ管新生の增加に影響することが示唆された。 